\title{
Concessive Participles and Epitactic Constructions in Ancient Greek*
}

\author{
José Miguel Jiménez Delgado \\ Universidad de Sevilla, Spain \\ jmiimdelg@us.es
}

\begin{abstract}
The purpose of this paper is to explain the construction of concessive participles introduced by kai taûta in Ancient Greek as an instance of epitaxis, a specific type of coordination. This construction will be differentiated from the concessive participles introduced by adverbial kaí, the usual construction, by its syntactic configuration and pragmatics. The data is drawn from the works of Xenophon of Athens (c. $430-354$ BC).
\end{abstract}

\section{Keywords}

concessive participles - coordination - information structure - additive particles epitaxis - tail (pragmatic function) - stripping

\section{Introduction}

In Ancient Greek it is relatively common to find concessive participles introduced by kaí. Concessive participles are a subtype of circumstantial participles which function as adverbial modifiers equivalent to a concessive subordinate clause. Their head can be a participant in the main clause, in which case they

* This paper has been written within the research project "Adverbios de foco en los historiadores griegos" (FFI2012-36944-C03-03) funded by Spain's Ministry of Economy and Competitiveness. I would like to express my gratitude to Emilio Crespo and Helena Maquieira for their comments on a previous version; to the participants of the Syntax of the World's Languages vi Conference, where I delivered a presentation on the same topic; and to the two anonymous reviewers. 
are called conjunct participles; or it can be an independent noun in the genitive case, with the participle in the genitive as well, and then one speaks of an absolute participle construction. The particle kai can function either as a copulative conjunction or as an additive focus adverb. When introducing concessive participles, kai usually functions as an adverb. This is a phenomenon common to a number of languages: the adverb presupposes the existence of less extreme alternatives as possible values for the hindrance expressed by the subordinate clause. In these cases, kai is usually followed by particles (kai-per, kaí-toi) or degree adverbs (kai mála, kai pánu, kai sphódra):

\section{(1) $\quad H G 7.4 .39$}

hoi dè akoúsantes ekeînon mén, kaíper they:pro ptc hear:aor:ptcp:nom.pl him:dem:acc ptc even:adv gignốskontes hóti epseúdeto perì sphôn, know:ipfv:ptcp:nom.pl that:comp lie:imperf:3sg about:prep them:gen aphíesan. acquit:aor:3pl

'Upon hearing this they acquitted him, although they knew that he was speaking falsely about them.' ${ }^{1}$

This paper focuses on the concessive participles introduced by kai taûta. In this case, kai functions as a conjunction coordinating the participle construction which belongs to an independent syntactic unit. After kaí, an anaphoric pronoun taûta appears, referring to the main clause. Accordingly, kai taûta examples normally emerge after their main clause, whereas other cases have less fixed positions:

(2) An. 2.4.15

kai proselthòn ánthrōpós tis èrótēse toùs and:ptc come-up:aor:ptcp:nom.sg man a:nom ask:aor:3sg the prophúlakas poû àn ídoi Próxenon $\grave{e}$ outposts:acc where:int ptc see:aor:opt:3sg Proxenus:nom or:ptc Kléarkhon; Ménōna dè ouk ezétei, kai Clearchus:nom Menon:acc ptc not:neg seek:imperf:3sg and:ptc

1 The English translations are those available at the Perseus Digital Library (http://www .perseus.tufts.edu), with slight changes when strictly necessary. The Greek texts are those of the TLG (http://www.tlg.uci.edu); the abbreviations referring to Xenophon's works follow the LSJ standard. I employ the Leipzig Glossing Rules, although superfluous details are omitted. 
taûta par' Ariaíou ò̀n tồ that:dem from:prep Ariaeus:gen be:ipfv:ptcp:nom.sg the:gen.sg Ménōnos xénou.

Menon's friend:gen

'A man came up and asked the outposts where he could see Proxenus or Clearchus - he did not ask for Menon, despite the fact that he came from Ariaeus, Menon's friend.'

In this example, a concessive participle construction is introduced by kai taûta after its main clause. Note that the participle is apparently embedded in the preceding clause, but kaí functions as a coordinating conjunction. The presence of the anaphoric pronoun taûta clarifies this point and makes the repetition of previous material unnecessary: "and that happened (= he did not ask for Menon) despite the fact that he came from Menon's friend" (the translation available at the Perseus Digital Library is a little bit simplistic regarding this point, as most translations are).

As is discussed further, this kind of coordination is epitactic. Hence, the paper starts with a definition of epitaxis, a construction whose frequency and vitality in Ancient Greek is also claimed. Subsequently, the concessive participle construction introduced by kai taûta is explained as an epictatic construction in contrast to the participles introduced by adverbial kaí. Finally, the pragmatic strategies underlying each participle construction are compared.

\section{$2 \quad$ Epitaxis in Ancient Greek}

Epitaxis is a particular form of coordination, described as asymmetrical, ${ }^{2}$ with a clear pragmatic function of highlighting the introduced information. The term was coined by Gagnepain (1963) after Gr. ह่ $\pi \imath \alpha \gamma \mu \alpha \tau i x o$ ' 'appositional' from $\dot{\varepsilon} \pi \imath \dot{\alpha} \sigma \sigma \omega$ 'to postpone' (Bécares 1985: s. uu.), and it is mostly used in Celtological studies. It has been defined by Rosén (2009: 413) as "the presentation of an additional rheme, thus bringing into focus an element that did not fig-

2 In the sense that the coordinated elements are of a dissimilar grammatical form (Rosén 1990 \& 2008: 206). Asymmetrische Koordination is a phenomenon studied mainly in German (Höhle 1990: 221-235), whereby the order of constituents is reversed in the second conjunct: "wenn jemand nach Hause kommt und da steht der Gerichtsvorzieher vor der Tür ..." [subject + verb :: verb + subject]. See also the definition of "asymmetrical" applied to and by Bonifazi (In press: § 11): "If $p$ and $q$ cannot equal $q$ and $p$, then "and" is asymmetrical". On symmetry in coordination, see Haiman (1985). 
ure in the preceding - syntactically and informationally saturated — sentence, provided this element is a secondary component (an adnominal adjunct or an adverbal one, whether adverb, "praedicativum", non-argumental case-form, prepositional phrase, or clause ...)". The term epitaxis is restricted to historical linguistics. From a more general perspective, epitaxis is a specific type of appendix or Tail, in Functional Grammar terms (Dik 1997b: 401-403), characterised by the presence of the coordinating conjunction (Slings 2002: 64). ${ }^{3}$

Epitaxis requires that the coordinated element constitutes an independent clause. This element is, however, tightly related to the previous clause to such an extent that Lambrecht (1994: 238 \& 356, n. 14) considers that the coordination somewhat breaks the sentence up. According to him, coordination is due to the fact that the proposition contains two different assertions in pragmatic terms, one expressed in the first clause and another expressed in the coordinated one. ${ }^{4}$ The redundant material is regularly omitted in the epitactic construction, although exceptions do exist (Rosén 2008: 221-224). Compare the following pair: ${ }^{5}$

(3) Cyr. 6.3.12

kaì gàr prò tês táxeōs taútēs álloi even:adv for:ptc in-front-of:prep the company this:gen other:nom.pl hōs triákonta hippeîs sukhnòn about:adv thirty horsemen:nom at-a-distance:adv proelaúnousi, kai méntoi ... kat' ride-forward:pres:3pl and:ptc indeed:ptc against:prep autoùs hēmâs.

ourselves:acc

'For at a considerable distance in advance of this company about thirty other horsemen are riding forward; as a matter of fact, they are riding in the direction of our party'.

3 Note that the coordinating conjunction can be ø; cf. Rosén (2008).

4 According to Lambrecht (1994: 52 ), pragmatic assertion is "The proposition expressed by a sentence which the hearer is expected to know or take for granted as a result of hearing the sentence uttered", while pragmatic presupposition is "The set of propositions lexicogrammatically evoked in a sentence which the speaker assumes the hearer already knows or is ready to take for granted at the time the sentence is uttered".

5 Epitaxis involves stripping, i.e., "a rule that deletes everything in a clause under identity with corresponding parts of a preceding clause, except for one constituent” (Hankamer \& Sag 1976: 409). 
(4) An. 7.6.17

Seúthēs ... apaitếsei me kai apaitései

Seuthes:nom demand-back:fut:3sg me:acc and:ptc (idem)

méntoi dikaíōs.

indeed:ptc with-justice:adv

'[... Seuthes will demand it back from me, and, moreover, he will demand it back with justice'.

In the first example, a prepositional phrase is epitactically introduced, and so it appears as the only overt syntactic constituent of its clause (kat' autoùs hèmâs 'against ourselves'). One can observe that the translation available at the Perseus Digital Library repeats the verb ("they are riding") in the coordinated clause, although it is omitted in the Greek original. In the second example, the introduced element is an adverb of manner (dikaíōs 'with justice'), but the main verb is repeated (apaitếsei 'he will demand back'). In this case, the particle méntoi is placed after the verb.

Epitaxis is a common construction in a number of IE and non-IE languages, including Latin (H. Rosén 2008); Celtic languages (Lambert 1985); Spanish (RAE: $\S 31.4 \mathrm{~W} \& \mathrm{x}$ ); German, in which the sequence und zwar is frequently used to introduce epitactic elements (Altmann 1981: 71; Behaghel 1923: § 1038; Engel 1996: 747; Günthner 2012); and Hebrew (Lambert 1984). Nevertheless, it has not been thoroughly studied in Ancient Greek. Rosén (2008: 239) goes so far as to state that "Ancient Greek epitaxis is highly constrained in its

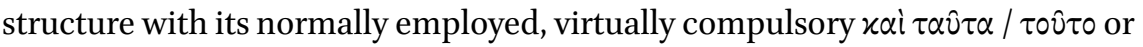

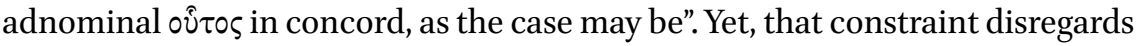
the variety exhibited by epitaxis in that language. On the other hand, epitactic constructions are only mentioned in the specific bibliography. See Denniston (1954: 291-292), Bäumlein (1861: 147-148), Kühner \& Gerth (1904: 246-247) and Smyth (1920: §947), who generally insists on the highlighting effect of this employment of kaí. This lack of attention is somewhat remarkable given that a careful examination of the texts reveals a surprising vitality. I have checked the occurrences of the most typical sequences introducing epitactic elements in the entire Xenophontean corpus, including Athēnaíōn politêa, whose authorship is disputed; see Jiménez (2013). According to my data, kai mála is epitactically used 22 times, ${ }^{6}$ kai pánu 5 times, ${ }^{7}$ and kai sphódra 2 times. ${ }^{8}$

\footnotetext{
6 An. 1.5.8, 3.1.29, 4.6.16, 5.6.15, 5.7.4, 6.1.32, Ap. 8, Cyr. 1.3.10, 4.2.46, 5.1.12, 7.5.50, HG 2.4.2, 4.1.25, 4.5.7, 4.7.2, 5.2.3, 5.4.16, 6.5.13, 7.1.19, 7.5.10, Mem. 3.11.10, Smp. 4.49.

7 An. 2.3.25, Cyr. 6.1.41, Oec. 1.22, 11.9, 13.1.

8 Oec. 3.4, Smp. 8.4 .
} 
Moreover, 28 occurrences of kait taûta ${ }^{9}$ must be added. These sequences consist of the conjunction kai followed by an adverb of degree or by an anaphoric pronoun:

(5) $\quad H G 4.7 .2$

ho dè apekrínato kaì mála katà

he:pro ptc answer:aor:3sg and:ptc quite:adv according-to:prep tautá.

the-same:acc.pl

'And he (Apollo) answered verbally, and he did hold quite the same opinion'.

(6) $\quad M e m \cdot 3 \cdot 7 \cdot 2$

oîmaí se dunatòn ónta okneîn

think:pres:1sg you:acc able:acc.sg be:ipfv:ptcp:acc.sg shrink:ipfv:inf epimeleîsthai, kaì taûta hôn anágkē take-care-of:ipfv:inf and:ptc that:dem what:rel:gen.pl obligation:nom soi metékhein políteie ge ónti. you:dat.sg take-part-in:ipfv:inf citizen:dat ptc be:ipfv:ptcp:dat.sg 'I fancy that you shrink from work that is within your powers, and work in which it is your duty as a citizen to take a hand'.

Example (5) is not evident, although it is selected by Rosén (2008: 234) for her illustration of epitaxis in Ancient Greek. It should be contextualised: the subject is the god Apollo who endorses the answer of his father Zeus (mála katà tautá "quite in the same way"), albeit in words, whereas Zeus has spoken through signs in victims. Buchsenschutz (1884: 189) and Grosser \& Ziegler (1899: 79) translate kai taûta in this passage by "und zwar", one of the most typical sequences introducing epitactic elements in German. In example (6), epitaxis is evident, even if the translation resorts to a (prepositional) object "(from) work", which is absent in the Greek original. This example is also syntactically more complex: taûta refers to the main clause and the relative clause coordinated by kai constitutes the true object of epimeleîsthai 'to take care of'.

9 Ag. 1.38, 2.24, 2.28, An. 1.4.12, 2.4.15, 6.2.10, 7.1.29, 7.6.35, Cyr. 1.6.45, 2.2.12, 2.2.16, 2.3.9, 5.3.30, HG 2.3.53, 5.1.17, 5.4.22, 6.5.37, Hier. 1.9, 7.8, Mem. 1.2.29, 2.2.5, 2.3.1, 3.7.2, Oec. 8.23, 11.3, 17.6, 20.28, Vect. 3.10. 
The cases are not reduced to those types, kaí + adverb of degree / taûta, as Rosén herself recognises (2008: 234). See, for instance, examples (3) and (4). In the following example, the epitactic construction is achieved by using állos te kaí:

\section{(7) $\quad H G 3 \cdot 3 \cdot 7$}

légein d'autòn éphē hóti kaì taùta say:ipfv:inf ptc him:acc state:aor:3sg that:comp also:adv those hópla pánt' eiēe hopósois ánthrōpoi kai weapons all:acc be:ipfv:opt:3sg which:rel:dat.pl men:nom and:ptc gên kai xúla kai líthous ergázontai ..., land:acc and:ptc timber:acc and:ptc stones:acc work:pres:3pl állōs te kai pròs aóplous. otherwise:adv and:ptc also:adv against:prep unarmed:acc.pl 'And he said, the informer continued, that all those tools with which men work the land and timber and stone were likewise weapons ..., and especially against unarmed men'.

The phrase állōs te kaí is a locution made up of three elements, the adverb of manner állōs 'otherwise, in another way' plus the additive particles te and kai. Note that this is the adverbial correspondent of the focalising expression

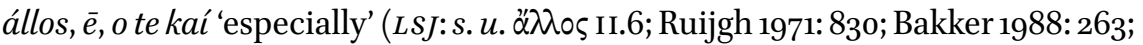
Crespo et al. 2003: 54), with the indefinite pronoun equivalent to Eng. 'another', állōs te kaí being used when the introduced element is indeclinable (Bonifazi in press: §125).

Epitactic constructions are fairly common in Ancient Greek and most of them are, to my knowledge, introduced by kaí. However, Denniston (1954: 317$318)$ and Thesleff $(1954: \S \S 41,61,106)$ consider kai an intensifier when it is followed by an adverb of degree; see also Smyth (1920: § 2882c) and Cooper (1998: 1350-1351). This is quite confusing (kai mála = 'exceedingly, certainly'), and it is not the case with taûta since the anaphoric pronoun cannot be intensified.

\section{Epitaxis, Concessive Participles, and kaì taûta in Ancient Greek}

As we have seen, the sequence kai taûta is one of the most typical in Greek epitactic constructions. Moreover, its use with concessive participles has already been described (Kühner \& Gerth 1904: 85 \& 247; Smyth 1920: § 2083; Cooper 1998: 854-855; LSJ S. U. ovं To5 VIII.2). In my opinion, the use of this sequence as a concessive marker is best captured within the frame of epitaxis. 
Before dealing with kai taûta itself, the usage of kaí with concessive participles must be considered in general. This usage includes both adverbial and coordinating kaí. Indeed, it is not always easy to determine whether kai functions as an adverb or as a coordinating conjunction. It is well known that kai is usually used as a concessive marker of circumstantial participles (Schwyzer \& Debrunner 1950: 389; Goodwin 1897: 341; Chantraine 1953: 320-321). This function can be carried out either by kai alone or in specific combinations (Bakker 1988: 140; Wakker 1994: 330), including kai per, kaí-toi (no example in Xenophon's works, but see LSJ S. U. III and Denniston 1954: 559), and kaí followed by adverbs of degree:

(8) Cyr. 5.1.26

sùn mèn soì hómōs kaì en têi

with:prep ptc you:dat however:adv even:adv in:prep the polemíái ontes tharroûmen.

enemy's:dat.sg be:ipfv:ptcp:nom.pl be-confident:pres:ipl

'with you we are not afraid even in the enemy's land'.

(9) $H G 4.3 .20$

ho dé, kaíper pollà traúmata ékhōn,

he:pro ptc even:adv many wounds:acc have:ipfv:ptcp:nom.sg

hómōs ouk epelátheto toû theíou.

however:adv not:neg forget:aor:3sg the deity:gen

'And he, although he had received many wounds, nevertheless did not forget the deity'.

(10) Mem. 2.4.4

horân éphē toùs polloùs tôn mèn állōn

see:ipfv:inf say:aor:3sg the many:acc.pl the:gen.pl ptc other

ktēmátōn, kaì pánu pollôn autô̂s

possessions:gen even:adv very:adv many:gen.pl. them:dat

óntōn, tò plêthos eidótas.

be:ipfv:ptcp:gen.pl the number:acc know:perf:ptcp:acc.pl

'I find-he said - that most men know the number of their other possessions, however great it may be'.

This development is associated with the general tendency of additive particles to evolve into concessive markers (König 1988: 153-154). That pattern is mostly exhibited by scalar additive particles (Haspelmath \& König 1998: 584587 ), which indicate that the event expressed in the subordinate clause is 
highly unexpected by presupposing the existence of less extreme alternatives as to the realisation of the main event (König 1991: 82-87; Wakker 1994: 329330 ).

However, kaí is a polyfunctional additive particle, which can be used as a copulative conjunction as well as an additive adverb, both simple and scalar. Ancient Greek is not an exception seeing as other languages show similar polyfunctional elements (König 1991: 65-66). In the above cases, the concessive participle construction is located within the main clause, and there is no coordination at the phrase level; accordingly, kai must be understood as an adverb. Notwithstanding, the function of kai as an adverb can be questioned when the construction follows the main clause. Compare the following pair:

(11) $H G$ 3.1.22

hoi d' apò tôn púrgōn kai mála

the:nom.pl ptc on:prep the towers:gen even:adv quite:adv

hupsēlôn óntōn horôntes tòn Meidiān

high:gen.pl be:ipfv:ptcp:gen.pl see:ipfv:ptcp:nom.pl the Meidias:acc sùn autôi ouk éballon.

with:prep him:dat not:neg throw:imperf:3pl

'Now the men on the towers, even though they were extremely high, saw Meidias with him and did not throw their missiles'.

(12) $H G 7 \cdot 5 \cdot 10$

diataxámenoi

hoi Spartiâtai

ephúlatton,

post:aor:ptcp:mid:nom.pl the Spartiatae:nom keep-guard:imperf:3pl

kai mála olígoi óntes.

and/even:ptc/adv quite:adv few:nom.pl be:ipfv:ptcp:nom.pl

'The Spartiatae posted themselves at various points and kept guard, although they were extremely few'.

In both passages, a concessive participle is found preceded by kai mála. The additive particle functions as a concessive marker, and mála is an adverb of degree modifying a following adjective as part of the "extremeness" proper to concessive circumstances (Wakker 1994: 330): in the first passage, the guards on the towers were able to visually identify the coming people in spite of the fact that those towers were very high; in the second, the Spartiatae prepared themselves to defend the city even though there were few of them to do so. In the first case, kai is an additive adverb. However, the position of the second example after the main clause can cause uncertainty about the syntactic status of kaí since (epitactic) coordination is possible in that position (Jiménez 2013). 
In the case of kai taûta, the adverbial interpretation of kaí is excluded. The focus of adverbial kai is usually the following element (Jiménez 2014), but in our cases kaí does not modify taûta. In these instances, taûta is an anaphoric pronoun referring back to the main clause, a function that cannot trigger the interpretation of kai as an adverb. ${ }^{10}$ On the contrary, it perfectly matches the conjunctive interpretation: kai functions as the coordinating conjunction of the participle construction with the preceding clause referred to by the pronoun; taûta is neuter plural in accordance with the complexity of its referent, a state of affairs (Schwyzer \& Debrunner 1950: 44). Accordingly, the construction normally follows its main clause:

(13) Ages. 1.38

etheloúsioi goûn autôi suneboéthēsan têi

voluntary:nom.pl ptc him:dat go-to-aid-with:aor:3pl the

Lakedaímoni, kaì taûta eidótes hóti

Sparta:dat and:ptc that:dem know:perf:ptcp:nom.pl that:comp

ou kheírosi heautôn deésoi

not:neg inferiors:dat themselves:gen be-necessary:fut:opt:3sg

mákhesthai.

fight:ipfv:inf

'At any rate, they went with him voluntarily to aid Sparta, knowing as they did that they must meet an enemy not inferior to themselves'.

(14) Cyr. 2.2.12

ho mèn gàr alazò̀n émoi=ge dokề

the:nom.sg ptc for:ptc impostor:nom me:dat=ptc seem:pres:3sg

ónoma keîsthai epi toîs ... poiêsein hà

name:acc lie:ipfv:inf on:prep those:dat do:fut:inf what:rel:acc.pl

mè hikanoí eisin hupiskhnouménois, kai

not:neg able:nom.pl be:pres:3pl promise:ipfv:ptcp:dat.pl and:ptc

taûta phaneroîs gignoménois hóti tô̂

that:dem evident:dat.pl become:ipfv:ptcp:dat.pl that:comp the:gen.sg

labeîn $t i$ héneka poioûsin.

get:aor:inf something:acc for-the-sake-of:prep do:pres:3pl

10 If taûta were modified by kaí, the referent of the pronoun would be in focus ("also / even that"). This cannot be categorically excluded but would imply an asyndeton that is fairly unexpected in Ancient Greek (Emilio Crespo, personal communication). Note that asyndeton can be mitigated by anaphoric pronouns like taûta (Denniston 1970: 109), even though taûta cannot be the focus and linking element of its clause at the same time. 
'For to me, the name 'humbug' seems to apply to those who promise to do what they cannot do, and that, too, when it is evident that they do this only for the sake of getting something'.

(15) An.6.2.10

hoi dè lógoi êsan autoîs hôs

the:nom.pl ptc words:nom be:imperf:3pl them:dat that:comp

aiskhròn eié ... toùs mèn pónous

shameful:nom.sg be:ipfv:opt:3sg the:acc.pl ptc hardships:acc

sphâss ékhein, tà dè kérdē állous,

themselves:acc have:ipfv:inf the:acc.pl ptc gains:acc others:acc

kaì taûta tè̀n sōtērían sphôn

and:ptc that:dem the preservation:acc themselves:gen

kateirgasménōn.

achieve:perf:ptcp:gen.pl

'Their words were to this effect, that it was shameful ... that the hardships should fall to themselves and the gains to others, all despite the fact that the preservation of the army was their achievement'.

In the previous passages, kai taûta introduces participle constructions with concessive meaning coordinated to their main clauses. The syntactic complexity varies and includes absolute constructions - as in (15) - which in Ancient Greek tend to be construed in the genitive case. On the other hand, final position after the main clause is characteristic of any kind of epitactic element, like the prepositional phrase parà tôi proxénōi in (16):

(16) $H G 5 \cdot 4.22$

ouk án pote hoútō môroi hôn hōs

not:neg ptc ever:adv so:adv foolish:nom.pl be:imperf:3pl that:comp

... en tôi ástei àn hupokheiríous hautoùs

in:prep the city:dat ptc subject:acc.pl themselves:acc

pareîkhon, kaì taûta parà tôi proxénōi,

offer:imperf:3pl and:ptc that:dem at:prep the diplomatic-agent:dat

hoû tákhist' àn hēuréthēsan.

where:rel most-speedily:adv ptc find:aor:pass:3pl

'[...] they would never have been so foolish as to put themselves in the power of the Athenians in the city, and, still less, at the house of their diplomatic agent, where they would most speedily be found'. 
From a semantic perspective, the construction of concessive participles introduced by kai taûta is also different from the construction with adverbial kaí. According to LSJ, kaì taûta adds "a circumstance heightening the force of what has been said". In our case, this heightening is related to the concessive nuance given that the state of affairs represented in the main clause takes place in spite of the hindrance expressed by the participle construction. The concessive effect brought about by invoking less extreme alternatives (the scalar additive particle construction) is obtained with kai taûta (the epitactic construction) by adding the hindering circumstance as an independent clause. In this way, no alternatives are invoked, but the realisation of the main event is emphasised by coordinating the hindrance. ${ }^{11}$

A similar construction is found in Spanish, where concessive clauses can be introduced by y eso que, by means of which "something previously stated by the speaker himself or by his interlocutor is made clear or highlighted" (Flamenco 1999: 3834). ${ }^{12}$ Note that Spanish $y$ is a copulative conjunction and eso an anaphoric pronoun, and they function together as a concessive subordinator (followed by que). ${ }^{13}$ On the contrary, the grammaticalisation of kai taûta as a concessive marker of participle constructions is incomplete. ${ }^{14}$ The circumstance denoted by the participle is not necessarily a hindrance, as can be seen in two Xenophontean passages:

(17) Ages. 2.28

ásmenos

ékousen

hóti

metepémpeto

autón,

delighted:nom.sg hear:aor:3sg that:comp send-for:imperf:3sg him:acc

\section{kaì taûta hēgemoníān hupiskhnoúmenos.}

and:ptc that:dem chief-command:acc promise:ipfv:ptcp:nom.sg

11 In the construction at issue, both the finite verb and the participle are factual; i.e. the hindrance does exist, but the main event takes place regardless.

12 "[...] se hace presente o se destaca algo manifestado previamente por el propio hablante o por el interlocutor". It must be noted that y eso que only introduces factual concessive clauses in the indicative.

13 According to Lambert (1985), epitaxis usually has a concessive nuance in Celtic languages.

14 One of the reviewers emphasises the placement of the construction of kaí + taut $t a+$ concessive participle in the continuum coordination-subordination and wonders whether its grammaticalisation as a concessive construction implies the passage from a coordinate structure (kaí + taûta + ellipsis + concessive participle) to a subordinate one (kaí + taûta + concessive participle). This suggests a reanalysis of conjunctive kaí as an adverb applicable to other cases in which taûta is not used, cf. (12). On the continuum coordinationsubordination, see Simone (2009) and Van Valin \& LaPolla (1997: 454). 
'He was delighted when a summons for help reached him (from the Egyptian king), who actually promised him the chief command'.

(18) Oe. 20.28

labóntes

hopóson

dúnantai pleîston

get:aor:ptcp:nom.pl as-much-as:rel:acc can:pres:3pl at-most:adv

ágousin autòn dià tês thaláttēs, kaì taûta

carry:pres:3pl it:acc through:prep the sea:gen and:ptc that:dem

eis tò ploîon enthémenoi en hôiper

in:prep the ship:acc put-in:aor:ptcp:nom.pl in:prep which:rel:dat.sg

autoi pléousi.

themselves:nom sail:pres:3pl

'[So deep is their love of corn that on receiving reports that it is abundant anywhere, merchants will voyage in quest of it] ... when they have got as much as possible, they carry it over the sea, and they actually stow it in the very ship in which they sail themselves'.

In both cases, kaì taûta introduces a participle construction, though neither of the denoted circumstances constitutes an impediment to the fulfilment of the main event. In fact, it is quite the opposite: both circumstances reaffirm that event by showing the commitment of its subject. Thus, kai taûta functions as a modificateur réalisant (MR) or reinforcing modifier (see Ducrot 1995: 147), ${ }^{15}$ whether it adds a negative or a positive circumstance to the previous sentence.

A Pragmatic Account for Concessive Participles Introduced by kai taûta

We have already seen that kaí in the sequence kai taûta does not function as an adverb when introducing concessive participles but as a coordinating conjunction. Accordingly, this participle construction is normally encountered following its main clause. There is only one possible exception out of the 14

15 'Un mot lexical $\mathrm{Y}$ est dit 'MD' (= modificateur déréalisant) par rapport à un prédicat $\mathrm{X}$ si et seulement si le syntagme XY: (i) n' est pas senti comme contradictoire, (ii) a une orientation argumentative inverse ou une force argumentative inférieure à celle de $\mathrm{X}$. Si $\mathrm{XY}$ a une force argumentative supérieure à celle de $\mathrm{X}$, et de même orientation, $\mathrm{Y}$ est un MR". 
instances of kaì taûta + concessive participle found in Xenophon's works: ${ }^{16}$ Oe. 8.23 ánthrōpon dé ge zētôn, kaì taûta eniote antizētoûnta, pollákis án tis próteron, prìn heureîn, apeípoi "But when you are searching for a person, you often fail to find him, though he may be searching for you himself.' ${ }^{17}$ In contrast, the position of the concessive participles introduced by other sequences is much less fixed: kai mála introduces a concessive participle 8 times within the main clause, 7 times after it; ${ }^{18}$ kai pánu 2 times within, one time after. ${ }^{19}$

This distribution is relevant in the differentiation of the concessive participle construction with kaì taûta from other constructions with kaí. In this regard, the position of the participle is significant for its pragmatic status:

(19) $H G 6.5 .20$

ho d'Agēsílāos kai mála

the:nom.sg ptc Agesilaus:nom even:adv quite:adv

boulómenos apágein tò stráteuma, ...

want:ipfv:ptcp:nom.sg lead-back:ipfv:inf the army:acc

hómōs ekê̂ katémeine trềs hēmérās ...

nevertheless:adv there:adv remain:aor:3sg three days:acc

'And Agesilaus, even though he was exceedingly desirous of leading back his army, nevertheless remained there for three days'.

16 Ag. 1.38, 2.24, An. 1.4.12, 2.4.15, 6.2.10, 7.1.29, Cyr. 2.2.12, 2.2.16, 2.3.9, HG 2.3.53, Mem. 2.3.1, Oec. 8.23, 11.3, 17.6.

17 The exception is to some extent apparent since taûta refers to the participle clause of zètôn, an imperfective circumstantial participle in the nominative case agreeing with tis 'anyone', which is the main clause subject. Even so, antizētoûnta, the participle following kaì taûta and agreeing with the accusative ánthrōpon, expresses an obstacle in the realisation of the main event whose finite verb is apeipoi. On the other hand, the clause of antizētoûnta might be interpreted as a concessive conditional one (Wakker 1994: 329-339; Haspelmath \& König 1998): "even if he may be searching for you himself". This interpretation is not found in the literature. See for instance Holden (1884: 168): vicissim et ipsum quaerentem, 'himself on his part looking for you'; and Holden (1895: 177): 'when he is himself looking for you'. In this regard, kai taûta only introduces pure concessive participles, while the concessive conditional type is associated with adverbial kaí.

18 An. 5.5.17, Cyr. 6.1.36, 8.3.38, HG 2.4.24, 3.1.22, 6.5.20, 6.5.21, Mem. 2.1.4. versus An. 3.1.29, 4.6.16, 6.1.32, Cyr. 4.2.46, 5.1.12, HG 5.2.3, 7.5.10.

19 Cyr. 5.1.15, Mem. 2.4.4 versus An. 2.3.25. 
(20) An. 7.1.29

bárbaron

mèn pólin oudemían èthelésamen kataskheîn, barbarian:acc.sg ptc city not-one:acc want:aor:ipl seize:aor:inf kaì taûta kratoûntes.

and:ptc that:dem be-conqueror:ipfv:ptcp:nom.pl

'We refrained from the seizure of any barbarian city, conquerors though we were'.

In the first case, the hindrance is introduced before the main verb to express a setting or frame, namely, a circumstance presented as background to the event denoted by that verb: Agesilaus, though he was desirous to go back, remained. This is the normal position of the participle constructions at issue when inserted within the main clause: before the main verb (katémeine) and after their own head (ho Agêsílāos). See Allan (2013) for the placement of the subject before a setting. Furthermore, it must be noted that in (19) the concessive structure is reinforced by using an adversative adverb hómōs 'nevertheless', which refers to the concessive clause within the main one (Redondo 2012; Ruiz Yamuza 2011; Quirk et al. 1985: 644-645). In the second case (20), the hindrance is attached after the main clause by coordination: the Athenians did not want to seize any barbarian city, and that despite being conquerors. Thus, the realisation of the main event is not questioned but stated, the hindering circumstance being appended as an independent assertion.

From a pragmatic perspective, adverbial clauses taking first positions usually establish a frame for the main clause (Allan 2013; Bertrand 2010: 294-298; Runge 2010: 207-268; Flamenco 1999: 3815-3816; Thompson 1985; Diessel 2001) ${ }^{20} \mathrm{Be}$ that as it may, Ancient Greek circumstantial participles have been typologically connected with converbs (Pompei 2012). ${ }^{21}$ In this respect, some of these participles are comparable to 'clause-chaining' or coordinative converbs on the

20 Settings are "adverbial phrases at the opening of clauses. Such phrases are like Topics in that they provide an orientation for the clause that follows, but they tend to be part of the spatial or temporal (or causal) organization of the text rather than themselves a participant about which the speaker provides information. Even more often than Topic constituents, Settings will provide information that is not previously given, yet has to be considered as presupposed" (H. Dik 2007: 36-37; see also Dik 1997b: 396-398). It must be stressed that settings can be found in different positions, though usually at the beginning of their sentence (Slings 1997: 173, n. 14; Bertrand 2010: 298).

21 A converb is defined as "a verb form which depends syntactically on another verb form, but it is not its syntactic actant, i.e. does not realizes its semantic valencies" (Nedjalkov 1995: 97). Nonetheless, Ancient Greek circumstantial participles are not prototypical converbs 
grounds that they have a symmetric discourse relation to their predicate (independent rhemes of Bary \& Haug 2011: $13^{-16) .}{ }^{22}$ This is not the case for our participles that are equivalent to conjunctional converbs as adverbial modifiers. As for the latter, Bary \& Haug (2011: 9-11) distinguishes elaborations, "participles which provide more information about the matrix event", from frames, "participles ... referring to events that have been mentioned in the previous discourse, or to events that are easily inferred". This distinction can be tied to the position of circumstantial participles following and preceding their matrix verb, respectively; see Haug (2012). At the same time, we have already seen that epitaxis has a pragmatic effect (Rosén 2009: 413; Lambrecht 1994: 356, n. 14), ${ }^{23}$ which is characteristic of reinterpreting structures (Fuentes 2009: 21; Fuentes 2012: 7981). In our examples, a circumstance affecting the realisation of the main event is added, yet it is not presented as a setting or frame in which that event takes place but as a restriction forcing a reconsideration of what has been said. This restriction is part of the assertion, i.e., it is not taken for granted or accommodated as background, but presented as the focus of its own proposition. ${ }^{24} \mathrm{On}$ the other hand, these reinterpreting structures are usually juxtaposed, whereas in the case being studied the copulative coordination makes it clear that the second assertion leads to the same conclusions from an argumentative point of view (Anscombre \& Ducrot 1983).

since they are adjectives agreeing with a noun in case, gender and number (Haspelmath 1995). Syntactically, these participles are under the scope of negation when their matrix clause is negated. In contrast, concessive participles are not, cf. (2), (9), (20).

23 See also the comments of Lambert (1985) on French “..., et cela ...": "la seule analyse plausible de cette tournure consiste à y voir: un connecteur (et), un thème (cela, = renvoi anaphorique au contenu de l'énoncé précédent), et un rhème. La formule ..., et cela ... introduit donc un second rhème dans la phrase".

24 Reinterpretation is one of the pragmatic functions of Tail, "a final constituent which falls outside the clause proper" (Dik 1997a: 418). According to H. Dik (2007, 35-36): "Tail describe[s] constituents that fall outside the clause proper ... when a speaker adds an extra constituent to a complete clause, by way of afterthought, further specification, or correction. Tail constituents ... will always be pragmatically marked: they are allotted a separate intonation unit, after all. Within those intonation units, ... Tail constituents should by definition be analysed as Focus (the most salient part of the intonation unit), but the clause itself will always have its own Focus constituent within it ...". Van der Wouden (2000) speaks of appendix, which he considers to be a focus position. Nevertheless, Tails can also have topic status when they are coreferent with a topic constituent; see Bertrand (2010: 287-293) and Allan (2013). 
Finally, it is interesting to note that the construction we have analysed is one of the constructions attested in Ancient Greek to bring about the highlighting of adverbial clauses. This pragmatic effect is usually achieved through cataphoric correlation (Matić 2003: 615-619; Bertrand 2010: 308-310), as well as through epitactic sequences like kaì taûta or allōs te kaí, which are similar to reinforcing pragmatic markers such as Span. eso sí, máxime, and sobre todo (Fuentes 2009; DPDE: s. uu.). In this regard, although kaitaûta specialises in the introduction of concessive participle clauses, it is also documented with other types of subordinate structures; see Hier. 7.8 kaì dôrá ge didóasin hoi polloi toútois hoùs misoûsi, kai taûta hótan málista phobôntai mế ti kakòn hup' autôn páthōsin "And as for presents, most men offer them to one whom they hate, and that too at the moment when they have cause to fear some evil at his hands". In this example, kai taûta is followed by a temporal clause introduced by the subordinator hótan whose verb phobôntai is a finite form.

Concessive participles introduced by kai taûta are to be classified among epitactic constructions, and therefore to be distinguished from concessive participle clauses introduced by adverbial kaí. Epitaxis is a particular kind of coordination whereby an element is coordinated with its sentence, constituting an independent syntactic unit as well as a second pragmatic assertion. The participles at issue are normally located after their main clause and coordinated by kaí, while taûta refers to the previous statement. This construction has a highlighting effect by adding a hindering circumstance that forces the reinterpretation of the main clause.

\section{References}

Allan, R.J. (2013) "Changing the topic: topic position in Ancient Greek word order", Mnemosyne 67/2, pp. 181-213.

Altmann, H. (1981) Die Gradpartikeln im Deutschen. Untersuchung zur ihrer Syntax, Semantik und Pragmatik, Tübingen, Narr.

Anscombre, J.-C. \& Ducrot, O. (1983) L'argumentation dans la langue, Bruxelles, Mardaga.

Bakker, E.J. (1988) Linguistics and formulas in Homer: scalarity and the description of the particle per, Amsterdam-Philadelphia, John Benjamins.

Bary, C. \& Haug, D.T. (2011) "Temporal anaphora across and inside sentences: The function of participles", Semantics and Pragmatics 4. 
Bäumlein, W. (1861) Untersuchungen über griechische Partikeln, Stuttgart, J.B. Metzler.

Bécares, V. (1985) Diccionario de terminología gramatical griega, Salamanca, Universidad de Salamanca.

Behaghel, O. (1923) Deutsche Syntax: eine geschichtliche Darstellung, Heidelberg, Carl Winter.

Bertrand, N. (2010) L'ordre des mots chez Homère: structure informationelle, localisation et progression du récit, Dissertation, Université de Paris-Sorbonne.

Bonifazi, A. (In press) "Multifunctionality of $\delta \dot{\varepsilon}$, $\tau \dot{\varepsilon}$, and $x \alpha i$ in the two Histories", in A. Bonifazi, A. Drummen \& M. De Kreij, Particles in Ancient Greek discourse. Pragmatic studies of particle use across genres, to appear.

Buchsenschutz, A.B. $\left(1884^{5}\right)$ Xenophons griechische Geschichte. Für den Schulgebrauch. Buch I-IV, Leipzig, Teubner.

Chantraine, P. (1953) Grammaire homérique. Tome II: syntaxe, Paris, Klincksieck.

Cooper, G.L. (1998) Attic Greek prose syntax, Ann Arbor, University of Michigan.

Crespo, E., Conti L. \& Maquieira, H. (2003) Sintaxis del griego clásico, Madrid, Gredos.

Denniston, J.D. $\left(1954^{2}\right)$ The Greek particles, Oxford, Clarendon Press.

Denniston, J.D. (1970) Greek prose style, Oxford, Clarendon Press.

Diessel, H. (2001) "The ordering distribution of main and adverbial clauses: a typological study", Language 77/3, pp. 433-455.

Dik, S. (1997a) The theory of functional grammar. Part 1: the structure of the clause, BerlinNew York, Mouton de Gruyter.

Dik, S. (1997b) The theory of functional grammar. Part 2: complex and derived constructions, Berlin-New York, Mouton de Gruyter.

Dik, H. (2007) Word order in Greek tragic dialogue, Oxford, University Press.

DPDE: Briz, A., Pons, S. \& Portolés, J. (coords.) (2008) Diccionario de partículas discursivas del español, online www.dpde.es.

Ducrot, O. (1995) “Les modificateurs déréalisants", Journal of Pragmatics 24, pp. 145165 .

Engel, U. (1996) Deutsche Grammatik, Heidelberg, Julius Groos.

Flamenco, L. (1999) "Las construcciones concesivas y adversativas", in I. Bosque \& V. Demonte (eds.), Gramática descriptiva de la lengua española, Madrid, EspasaCalpe, pp. 3805-3878.

Fuentes, C. (2009) Diccionario de conectores y operadores del español, Madrid, Arco/ Libros.

Fuentes, C. (2012) "El margen derecho del enunciado", RSEL 42/2, pp. 63-93.

Gagnepain, J. (1963) Syntaxe du nom verbal dans les langues celtiques, I: Irlandais, Paris, Klincksieck.

Goodwin, W.W. $\left(1897^{3}\right)$ Syntax of the moods and tenses of the Greek verb, Boston, Ginn \& Company. 
Grosser, R. \& Ziegler, E. $\left(1899^{2}\right)$ Xenophons Hellenika. Für den Schulgebrauch. Buch III$I V$, Gotha, Friedrich Andreas Perthes.

Günthner, S. (2012) "Eine interaktionale Perspektive auf Wortarten: das Beispiel 'und zwar', in B. Rothstein (ed.), Nicht-flektierende Wortarten, Berlin-Boston, de Gruyter, pp. 14-47.

Haiman, J. (1985) “Symmetry", in J. Haiman (ed.), Iconicity in syntax, Amsterdam-Philadelphia, John Benjamins, pp. 73-95.

Hankamer, J. \& Sag, I. (1976) “Deep and surface anaphora”, Linguistic Inquiry 7, pp. 391426.

Haspelmath, M. (1995) "The converb as a cross-linguistically valid category”, in M. Haspelmath \& E. König (eds.), Converbs in cross-linguistic perspective, Berlin, Mouton de Gruyter, pp. $1-55$.

Haspelmath, M. \& König, E. (1998) "Concessive conditionals in the languages of Europe", in J. van der Auwera (ed.), Adverbial constructions in the languages of Europe, Berlin, Mouton, pp. 563-640.

Haug, D.T. (2012) "Open verb-based adjuncts in New Testament Greek—with a view to the Latin Vulgate translation”, in C. Fabricius-Hansen \& D.T. Haug (eds.), Big events, small clauses: the grammar of elaboration, Berlin, Walter de Gruyter, pp. 287-321.

Höhle, T.N. (1990) "Assumptions about asymmetric coordination in German", in J. Mascaró \& M. Nespor (eds.), Grammar in progress: Glow essays for Henk van Riemsdijk, Dordrecht, Foris, pp. 221-235.

Holden, H.A. (1884) The Oeconomicus of Xenophon, London, Macmillan.

Holden, H.A. $\left(1895^{5}\right)$ The Oeconomicus of Xenophon, London, Macmillan.

Jiménez, J.M. (2013) “Kai $\mu \alpha ́ \lambda \alpha$ : estructuras de focalización y polaridad positiva”, Veleia 30, pp. $249^{-258 .}$

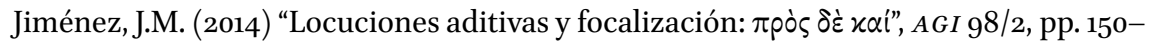
174.

König, E. (1988) "Concessive connectives and concessive sentences: cross-linguistic regularities and pragmatic principles", in J. Hawkins (ed.), Explaining language universals, Oxford, Blackwell, pp. 145-185.

König, E. (1991) The meaning of focus particles: a comparative perspective, London, Routledge.

Kühner R. \& Gerth, B. $\left(1904^{3}\right)$ Ausführliche Grammatik der griechischen Sprache. Zweiter Teil: Satzlehre. II. Band, Hannover-Leipzig, Hahn.

Lambert, P. (1984) “La conservation d'un hébraïsme dans les traductions celtiques de la Bible", Lalies 3, pp. 71-79.

Lambert, P. (1985) L'épitaxe dans les langues celtiques, Dissertation, Université de ParisIII.

Lambrecht, K. (1994) Information structure and sentence form: topic, focus, and the mental representations of discourse referents, Cambridge, University Press. 
LSJ = Liddell, H.G., Scott, R. \& Jones, H.S. $\left(1940^{9}\right)$ A Greek-English lexicon, Oxford, Clarendon Press.

Matić, D. (2003) “Topic, focus, and discourse structure. Ancient Greek word order", Studies in Language 27/3, pp. 573-633.

Nedjalkov, V. (1995) "Some typological parameters of converbs", in M. Haspelmath \& E. König (eds.), Converbs in cross-linguistic perspective, Berlin, Mouton de Gruyter, pp. $97^{-136 .}$

Pompei, A. (2012) "Participio greco e converbi", AGI 97/2, pp. 160-204.

Quirk, R., Greenbaum, S., Leech, G. \& Svartvik, J. (1985) A comprehensive grammar of the English language, London-New York, Longman.

RAE = Real Academia Española (2009-2011) Nueva gramática de la lengua española, Madrid, Espasa.

Redondo, E. (2012) "Estudio del adverbio conjuntivo ö $\mu \omega \varsigma$ en la novela griega", in A. Cabedo \& P. Infante (eds.), Lingüística XL. El lingüista del siglo XXI, Madrid, SE L ediciones, pp. 201-208.

Rosén, H. (1990) "La coordination asymétrique comme critère de fonction syntaxique en latin", L'Information Grammaticale 46, pp. 34-37.

Rosén, H. (2008) "Latin epitaxis in historical and typological view", in G. Calboli (ed.), Papers on grammar $X$, Roma, Herder, pp. 205-242.

Rosén, H. (2009) “Coherence, sentence modification and sentence-part modificationthe contribution of particles", in P. Baldi \& P. Cuzzolin (eds.), New perspectives on Latin historical syntax. Volume I: syntax of the sentence, Berlin-New York, Mouton de Gruyter, pp. 317-441.

Ruijgh, C.J. (1971) Autour de 'te épique.' Études sur la syntaxe grecque, Amsterdam, Hakkert.

Ruiz Yamuza, Emilia (2011) "Apodotic uses between syntax and text", in International Conference on Linguistics and Classical Languages, Rome, to appear.

Runge, S.E. (2010) Discourse grammar of the Greek New Testament: a practical introduction for teaching and exegesis, Peabody (MA), Hendrickson Publishers Marketing.

Schwyzer, E. \& Debrunner, A. (1950) Griechisches Grammatik II: Syntax und syntaktische Stilistik, München, Beck.

Simone, R. (2009) “Qu'y a-t-il entre coordination et subordination?”, in M.-J. Béguelin, M. Avanzi \& G. Corminboeuf (eds.), La parataxe: entre dépendance et intégration, Bern, Peter Lang, vol. I, pp. 231-253.

Slings, S.R. (1997) "Figures of speech and their lookalikes: two further exercises in the pragmatics of the Greek sentence", in E.J. Bakker (ed.), Grammar as interpretation: Greek literature and its linguistics context, Leiden, J.C. Brill, pp. 169-214.

Slings, S.R. (2002) "Oral strategies in the language of Herodotus", in E.J. Bakker, I.J.F. de Jong \& H. van Wees (eds.), Brill's companion to Herodotus, Leiden, J.C. Brill, pp. 5377 . 
Smyth, H.W. $\left(1920^{2}\right)$ A Greek grammar for colleges, New York, American Book Company.

Thesleff, H. (1954) Studies on intensification in Early and Classical Greek, Helsingfors, Centraltrykeriert.

Thompson, S.A. (1985) "Grammar and written discourse: initial vs. final purpose clauses in English", Text 5/1-2, pp. 55-84.

Wakker, G.C. (1994) Conditions and conditionals: an investigation in Ancient Greek, Amsterdam, J.C. Gieben.

Van Valin, R.D. \& LaPolla, R.J. (1997) Syntax: structure, meaning, and function, Cambridge, Cambridge University Press.

Van der Wouden, T. (2000) "Focus on appendices in Dutch", Linguistics in the Netherlands 17 , pp. 233-245. 